\title{
ATTITUDE ANALYSIS OF “THE GUARDIAN" EDITORIAL: LOCKDOWN POLICY AND THE GOVERNMENT
}

\author{
1Ratih Laily Nurjanah \\ ${ }^{1}$ Universitas Ngudi Waluyo

\section{Corresponding email: ratih.laily@gmail.com}

\section{Abstract}

This study aims to analyze the presented attitude based on the choice of words in an editorial published by The Guardian on November $5^{\text {th }}, 2020$ entitled "The Guardian View on the New Lockdown: Fewer Promises, Better Performance Needed". One of the most relevant discourses to be analyzed is editorial section of newspaper that is considered as the purest part of mass media reflected ideology, or in this case, political stance. This is a qualitative study using the method of Systemic Functional Language framework with the specification of interpersonal meaning especially appraisal analysis with 22 appraising items taken from the editorial as the sources of data. The findings show that The Guardian is more likely not standing on the same side as the government by giving more negative attitude than the positive ones in terms of affects, judgment, and appreciation. Getting involved in attitude analysis as a part of SFL is considered important in ELT process to help students use language appropriately started from small unit like word.

Keywords: Attitude analysis, appraisal system, editorials, SFL

\section{INTRODUCTION}

Appraisal theory has been developed by Martin \& White (2005) based on the interpersonal systems of Halliday. It works with negotiate attitude in discourse. Appraisal as a framework under SFL discusses the ways the speakers form certain identities and how to put themselves in front of people they are having communication with. Analyzing the language used by speakers provides the view on speaker's belief, objectives, and relationship with the others (Haristyanti, 2015)

Attitude as a part of appraisal system can be defined as judgment and appreciation to the human behavior, text, process or phenomenon affected by attitude. The resources can be categorized into 3; affect system (emotional expressions to human), judgment system (assessment from human to human), 
appreciation (evaluation of the valuable things). The 2 latter are defined based on the affect system as the center of the theory $(\mathrm{Li}, 2016)$.

Affect is the center of the three subsystems of attitude concerning the stating of positive and negative feelings; happiness, sadness, anxiety, boredom. This system can be divided into; quality, process, and omment.

Affect as quality is related to the use of process clause in expressing emotions. Affect as process is defined as the use of process clause to express feelings, especially mental and behavioral process. Affect as comment is described as the modal adjunct to comment on the clause process. It covers how positive or negative emotions are shown through words. It includes dis/inclination, un/happiness, in/security, and dis/satisfaction.

Judgment covers the attitudes to behavior that we admire, criticize, or condemn. It can be divided into social esteem, and social sanction.

Social esteem deals with 'normality' (how unusual someone is), 'capacity' (how capable they are) and 'tenacity' (how resolute they are) while sanction deals with 'veracity' (how truthful someone is) and 'propriety' (how ethical someone is). All of them are indicated by positive or negative judgment.

Appreciation includes evaluations of semiotic and natural phenomena related to the ways in which they are valued or not in a given field. Generally, it is categorized into positive or negative 'reactions' to things (do they catch our attention; do they please us?), the 'composition' (balance and complexity), and their 'value' (how innovative, authentic, timely).

The appraisal system specifically points out the subjective ideology of the users by evaluating the vocabulary. Polarity and explicitness are the important features of Attitude. Polarity is the feature to express the attitude of approval or disapproval through positive or negative attitude. Explicitness works on the ways of evaluation whether it is explicit or implicit (Dong \& Lin, 2018).

Attitude system can be found and analyzed easily in opinion since it is delivered based on someone's perspectives on something or other opinion stated by someone else. This kind of expression is published in newspaper under the editorial columns. Editorials are presented in different format because it is the only part of the newspaper showing organization of the paper. It also shows newspapers' editorial opinion-leading role. It plays a role to provide opinion and push issues as independent parts of politics. (Firmstone, 2015).

Editorials play important roles as stated by researchers including informing and shaping debate in public through 4 ways; 1) influencing readers, voters, or public opinions, 2 ) influencing internal news agendas and the scope of the newspaper, 3) influencing the agendas and scopes of other news media, 4) influencing politics or political agenda (Firmstone, 2020). 
Therefore, editorials can be viewed as personal opinion or ideology related to a topic that is served in forms of an article or a column for society. By delivering an opinion on a topic, editorials are expected to be able to persuade readers or watchers to agree on an issue. The persuasion involves symbols to transmit the message with language full of cultural meaning. They can be presented in words like freedom, justice, and equality; nonverbal signs like the flag, Star of David, or Holy Cross; and images that are instantly recognized. Here, symbols are used as tools to persuade readers leading to change of attitude and build opinions (Perloff, 2003). In this case, the tools used to deliver the message is the choice of words used in the editorial post analyzed from appraisal system point of view to conclude the attitude wanted to be shown by the publisher about the political issue especially on how government handles the Covid-19 outbreak.

The editorial staff of newspaper contributes to posing ideological arguments expected to influence readers through linguistic choices (Awan \& Harun, 2015).

The editorial column is a clear manifestation of the newspaper commitment to the society through participation in delivering opinions. The newspapers provide a place to exchange commitment and criticism and a common carrier of public expressions. Editorials also provide leadership issues that is prominent to community (Ugondo, 2018).

SFL as a system can be reflected in ELT where it focuses on understanding the social, linguistic processes and products of literacy. As explained by the seminal work on cohesion of Halliday and Hasan (1976) and Martin and Rose (2007), SFL has been greatly concerned with discourse. (Perales-escudero et al., 2018).

Working with short texts to start can be very helpful for students. The texts can be taken from short stories or excerpts to help students gain understanding about the role of language within the text. It also forms stamina for linguistic analysis and encourages deep thinking as a foundation for critical analysis of long texts (Schulze, 2015).

In terms of written discourse, teaching grammar is simply the way to achieve the goal of communication through written text. Since every aspect of a sentence plays important role in conveying meaning through grammar, it is very important for students to see grammar as a set of rules to be applied to make their text or written discourse meaningful.

The process of teaching discourse is a long one because it is expected that teachers or lecturers build students' understanding step by step by the scaffolding technique.

The scaffolding processes in teaching phases of writing can be implemented in macro and micro levels (Syarifah \& Gunawan, 2015). The result of this research showed that macro scaffoldings that are implemented in all of 
teaching phases while the micro one happens in some stages of teaching, especially in building knowledge of the field and modelling. Micro scaffolding can be implemented in joint construction of texts but not in independent text-construction. Macro scaffoldings that are implemented can be seen from the teaching objectives delivered by teachers, the tasks given to students, and the classroom organized by teachers.

The research question in this study is "What is the attitude shown by the editor of The Guardian based on the choice of words?" This paper aims to analyze and describe the attitude stated in the editorial column based on the choice of words. This paper works on the editorial related to the government policy on national lockdown due to Covid-19 outbreak.

\section{METHODS}

\section{Research Design}

This study applies qualitative design study that aims to describe the use of words reflecting the affect, judgment, and appreciation to determine the stance of The Guardian as one of the newspapers in London.

\section{Object}

The text analyzed is the editorial column of The Guardian posted on November $5^{\text {th }}, 2020$ entitled "The Guardian View on the New Lockdown: Fewer Promises, Better Performance Needed" with 22 appraising items analyzed.

\section{Data Collection}

The sources of data in this study are sentences written in the editorial of The Guardian.

\section{Instruments}

The method used in this study is Systemic Functional Language framework with the specification of interpersonal meaning especially appraisal analysis. Appraisal Theory is considered as an effective framework in terms of analyzing attitudes expressed and interpersonal meanings in various types of discourse such as literary works, news, legal, scientific and academic discourse.(Wei et al., 2015)

\section{Data Analysis Procedures}

First, the text of editorial was broken down into segments presented in table. Second, the sentences were then observed to see if each of them contains word that indicates the affect, judgment, and appreciation as stated in literature reviews. 
Affect is analyzed based on positive or negative affect so are judgment and appreciation. After analyzed in terms of positivity or negativity, then each category of affect, judgment, and appreciation is analyzed based on each own category.

\section{FINDINGS}

Table: 1 Findings of Attitude Analysis

\begin{tabular}{|c|c|c|c|c|}
\hline \multirow{3}{*}{ No. } & \multirow{2}{*}{ Appraising items } & \multicolumn{3}{|c|}{ Attitude } \\
\hline & & Affect & Judgement & Appreciation \\
\hline & 1 & 2 & 3 & 4 \\
\hline 1 & $\begin{array}{l}\text { Boris Johnson is still } \\
\text { suggesting it could all be } \\
\underline{\text { over by Christmas }}\end{array}$ & $\begin{array}{c}+ \\
\text { Inclination: } \\
\text { desire }\end{array}$ & & \\
\hline 2 & $\begin{array}{l}\text { The public, as well as } \\
\text { Conservative MPs, can be } \\
\text { forgiven for scepticism. }\end{array}$ & $\begin{array}{l}\text { - } \\
\text { Insecurity: } \\
\text { disquiet }\end{array}$ & & \\
\hline 3 & $\begin{array}{l}\text { The government has made } \\
\text { too many promises on } \\
\text { coronavirus, and done too } \\
\text { little, too late, too often. }\end{array}$ & $\begin{array}{l}- \\
\text { Dissatisfaction: } \\
\text { displeasure }\end{array}$ & $\begin{array}{l}\text { - } \\
\text { Capacity: } \\
\text { criticize }\end{array}$ & $\begin{array}{l}- \\
\text { Reaction: } \\
\text { Impact }\end{array}$ \\
\hline 4 & $\begin{array}{l}\text { How high the daily death } \\
\text { tolls rise, and how long they } \\
\text { continue, will depend on } \\
\text { whether the government } \\
\text { and public use these four } \\
\text { weeks wisely }\end{array}$ & & & $\begin{array}{c}+ \\
\text { Composition: } \\
\text { balance }\end{array}$ \\
\hline 5 & $\begin{array}{l}\text { The abrupt announcement } \\
\text { by the chancellor.... }\end{array}$ & $\begin{array}{l}- \\
\text { Insecurity: } \\
\text { surprise }\end{array}$ & $\begin{array}{l}- \\
\text { Propriety: } \\
\text { condemn }\end{array}$ & $\begin{array}{l}\text { - } \\
\text { Reaction: } \\
\text { Quality }\end{array}$ \\
\hline 6 & $\begin{array}{l}\text { Extending the furlough } \\
\text { scheme until March was a } \\
\text { welcome but too tardy. }\end{array}$ & $\begin{array}{c}+ \\
\text { Happiness: } \\
\text { cheer }\end{array}$ & $\begin{array}{l}+ \\
\text { Normality: } \\
\text { admire }\end{array}$ & $\begin{array}{l}+ \\
\text { Reaction: } \\
\text { Quality }\end{array}$ \\
\hline 7 & $\begin{array}{l}\text { Extending the furlough } \\
\text { scheme until March was a } \\
\text { welcome but too tardy. }\end{array}$ & $\begin{array}{l}\text { Dissatisfaction: } \\
\text { ennui }\end{array}$ & $\begin{array}{l}\text { - } \\
\text { Capacity: } \\
\text { criticise }\end{array}$ & $\begin{array}{l}\text { - } \\
\text { Reaction: } \\
\text { Quality }\end{array}$ \\
\hline 8 & $\begin{array}{l}\text { Restrictions could yet be } \\
\text { tightened: while keeping } \\
\text { schools open has been a } \\
\text { priority }\end{array}$ & & $\begin{array}{l}+ \\
\text { Normality: } \\
\text { admire }\end{array}$ & \\
\hline
\end{tabular}




\begin{tabular}{|c|c|c|c|c|}
\hline \multirow{3}{*}{ No. } & \multirow{2}{*}{ Appraising items } & \multicolumn{3}{|c|}{ Attitude } \\
\hline & & Affect & Judgement & Appreciation \\
\hline & 1 & 2 & 3 & 4 \\
\hline 9 & $\begin{array}{l}\text { Restrictions could yet be } \\
\text { tightened: while keeping } \\
\text { schools open has been a } \\
\text { priority- for good reasons. }\end{array}$ & $\begin{array}{l}+ \\
\text { Happiness: } \\
\text { cheer }\end{array}$ & $\begin{array}{c}+ \\
\text { Propriety: } \\
\text { praise }\end{array}$ & $\begin{array}{c}+ \\
\text { Reaction: } \\
\text { Quality }\end{array}$ \\
\hline 10 & $\begin{array}{l}\ldots . . . . \text { it may not be right if } \\
\text { the picture becomes much } \\
\text { worse. }\end{array}$ & $\begin{array}{l}\text { - } \\
\text { Unhappiness: } \\
\text { Antipathy }\end{array}$ & $\begin{array}{l}\text { - } \\
\text { Propriety: } \\
\text { condemn }\end{array}$ & $\begin{array}{c}\text { - } \\
\text { Reaction: } \\
\text { Quality }\end{array}$ \\
\hline 11 & $\begin{array}{l}\text { it may not be right if the } \\
\text { picture becomes much } \\
\text { worse. }\end{array}$ & $\begin{array}{l}\text { Unhappiness: } \\
\text { Antipathy }\end{array}$ & $\begin{array}{l}- \\
\text { Propriety: } \\
\text { condemn }\end{array}$ & $\begin{array}{l}\text { Composition: } \\
\text { Complexity }\end{array}$ \\
\hline 12 & $\begin{array}{l}\text {..........rules is unfair and } \\
\text { ill-advised.......... }\end{array}$ & $\begin{array}{l}\text { Unhappiness: } \\
\text { misery }\end{array}$ & $\begin{array}{l}- \\
\text { Propriety: } \\
\text { condemn }\end{array}$ & $\begin{array}{c}\text { Reaction: } \\
\text { Quality }\end{array}$ \\
\hline 13 & $\begin{array}{l}\text { The government must take } \\
\text { the rap........... }\end{array}$ & $\begin{array}{c}+ \\
\text { Inclination: } \\
\text { desire }\end{array}$ & & \\
\hline 14 & $\begin{array}{l}\text { for ill-judged, short-lived } \\
\text { and confusing policies and } \\
\text { messages }\end{array}$ & $\begin{array}{l}\text { Unhappiness: } \\
\text { misery }\end{array}$ & $\begin{array}{l}- \\
\text { Propriety: } \\
\text { condemn }\end{array}$ & $\begin{array}{l}\text { - } \\
\text { Reaction: } \\
\text { Quality }\end{array}$ \\
\hline 15 & $\begin{array}{l}\text { While people have a duty to } \\
\text { act responsibly focusing on } \\
\text { individual breaches is } \\
\text { neither sensible nor helpful }\end{array}$ & & $\begin{array}{l}+ \\
\text { Capacity: } \\
\text { admire }\end{array}$ & \\
\hline 16 & $\begin{array}{l}\text {....... focusing on individual } \\
\text { breaches is neither sensible } \\
\text { nor helpful }\end{array}$ & $\begin{array}{l}\text { - } \\
\text { Unhappiness: } \\
\text { misery }\end{array}$ & $\begin{array}{l}\text { - } \\
\text { Tenacity: } \\
\text { criticise }\end{array}$ & Valuation \\
\hline 17 & $\begin{array}{l}\text { The government must do a } \\
\text { better job of } \\
\text { communicating...... }\end{array}$ & $\begin{array}{c}+ \\
\text { Inclination: } \\
\text { desire }\end{array}$ & & \\
\hline 18 & $\begin{array}{l}\text { Sir Simon's clear } \\
\text { explanation at Thursday's } \\
\text { press conference showed } \\
\text { what could be done }\end{array}$ & & $\begin{array}{l}+ \\
\text { Normality: } \\
\text { admire }\end{array}$ & $\begin{array}{c}+ \\
\text { Reaction: } \\
\text { Impact }\end{array}$ \\
\hline 19 & $\begin{array}{l}\text {.......has fuelled the sense } \\
\text { that the government is more } \\
\text { concerned about.......... }\end{array}$ & $\begin{array}{l}\text { - } \\
\text { Unhappiness: } \\
\text { antipathy }\end{array}$ & & \\
\hline 20 & $\begin{array}{l}\text { For its own sake, and for the } \\
\text { union's, the government }\end{array}$ & $\stackrel{+}{+}+\frac{1}{\text { Inclination: }}$ & & \\
\hline
\end{tabular}




\begin{tabular}{|c|c|c|c|c|}
\hline \multirow{3}{*}{ No. } & \multirow{2}{*}{ Appraising items } & \multicolumn{3}{|c|}{ Attitude } \\
\hline & & Affect & Judgement & Appreciation \\
\hline & 1 & 2 & 3 & 4 \\
\hline \multirow{3}{*}{21} & $\begin{array}{l}\text { must engage in real } \\
\text { consultation with regional } \\
\text { and national leaders. }\end{array}$ & desire & & \\
\hline & They have profoundly & - & - & - \\
\hline & $\begin{array}{l}\text { negative effects on } \\
\text { individuals, communities } \\
\text { and the economy }\end{array}$ & $\begin{array}{l}\text { Unhappiness: } \\
\text { misery }\end{array}$ & $\begin{array}{l}\text { Normality: } \\
\text { criticise }\end{array}$ & $\begin{array}{l}\text { Reaction: } \\
\text { Impact }\end{array}$ \\
\hline \multirow[t]{2}{*}{22} & . They may fear that what & - & - & - \\
\hline & $\begin{array}{l}\text { the prime minister called } \\
\text { light at the end of the tunnel } \\
\text { could be another train } \\
\text { coming: a certain sense of } \\
\text { hopelessness as well as } \\
\text { weariness is evident. }\end{array}$ & $\begin{array}{c}\text { Disinclination: } \\
\text { fear }\end{array}$ & $\begin{array}{l}\text { Propriety: } \\
\text { condemn }\end{array}$ & Valuation \\
\hline
\end{tabular}

\section{Affect (A component of Attitude Analysis)}

Affect is defined as a set to express emotions. In this editorial, it is found that there are 18 affects used consisting of; 6 positive affects and 12 negative affects.

In item number (1), the word suggesting is used to show the writer's emotion related to the condition of national lockdown. Suggesting reflects positive affect of inclination especially desire. In this case, it is the desire of the writer to show that someone wants it to happen.

In item number (2), skepticism occurs to show public's insecurity especially disquiet. This is a negative affect emphasizing public's emotion towards the condition.

In item number (3), too little, too late, too often shows the negative affect of dissatisfaction especially displeasure. Those terms show how the government handles the situation that causes emotions to public. Through these terms, the emotions of being dissatisfied are reflected and highlight the displeasure felt by public.

In item number (5), abrupt can be viewed as insecurity especially surprise. This shows negative emotion to the word announcement.

Item number (6), welcome, shows positive affect of happiness. Emotion of cheer is involved in this item to make the sentence show positive emotion.

In number (7), tardy shows the writer emotion of feeling dissatisfied due to late response from the government.

In number (9), good shows the emotion of happiness especially cheer to the government step of opening the school. 
It may not be right (10) shows negative affect of emotion especially antipathy since the writer indicates his opinion about a phenomenon.

Related to number (10), number (11) worse shows also unhappiness affect especially antipathy.

Number (12) and (14) show similar affect of unhappiness/ misery because they show their affect or emotions towards things issued by the government. This is also found in number (16) and (21).

Number (13) must take positive affect of inclination/ desire since it shows what the writer wants the government to do. It gives personal suggestion on what should happen or be shown by the government.

The affect is also shown in number (20). By saying "must", the writer shows that he has something to tell to the government. It is used as tool to delivering their opinion. This shows positive affect since the opinion can be considered as the result of observation from writer.

Number (22) shows negative affect of fear. Fear, hopelessness and weariness were chosen by the writer to depict that public starts worrying or being afraid of the consequences that may occur because of the steps taken by the prime minister.

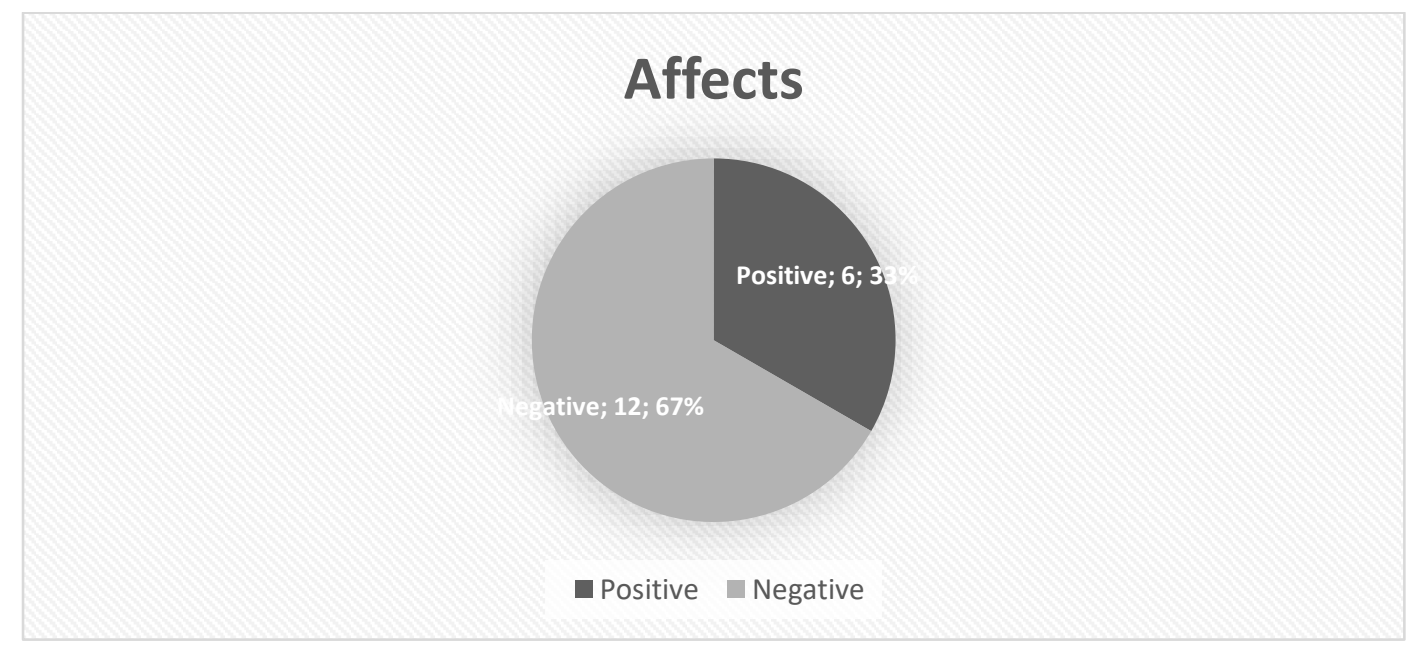

Figure 2. The Diagram of Affect Findings

From the diagram, we can see that unhappiness occurs 7 times from 18 appraisal items analyzed in the editorial or in other words, it occupies $22 \%$ of the items. The least item is disinclination which only occupies $0.05 \%$ of the analysis results.

\section{Judgment}

Judgment aspect is related to the attitude given or shown towards behavior whether we admire or even condemn the behavior. In this editorial page, 
there are some judgments shown, as expected, since it is important to see how the editor/ writer respond the government.

In number (3), too little, too late, too often is a negative judgment towards the government's capacity in handling the issue. It criticizes the ability of the government to handle the situation during the pandemic.

Abrupt in number (5) is used to show the reaction to the announcement from the government. It is a negative judgment of propriety falling to condemn category.

On the other hand, welcome (6) is used to show positive judgment towards the extended furlough scheme. It is categorized into normality judgment of admire.

But the word tardy (7) which is put in the same sentence of welcome (6) shows negative judgment towards the phenomenon by criticizing the government's capability.

Again, positive judgment of normality in admire is shown in word priority. It is categorized to normality especially admire showing that the phenomenon is special.

The positive judgment is also implied in number (9); good. It shows negative propriety of praise by stating that keeping the schools open is good for some reasons.

In numbers (10), (11), (12), and (14) the same negative judgment of propriety is shown. The writer shows that he/she condemns the results coming from the things done by the government.

After all negative judgment, a positive one of admire is shown in number (15). The writer gives positive judgment to the government's capacity by being responsible.

But again, negative judgment is shown in number (16) by criticizing the act of government to focus on individual breaches during the pandemic. The same judgment is also shown in number (21).

The writer gives positive judgment towards Sir Simon's explanation by calling it "clear". This is a normality especially admire judgment.

The condemn judgment, again, occurs in number (22) as a response to the statement from the government. 


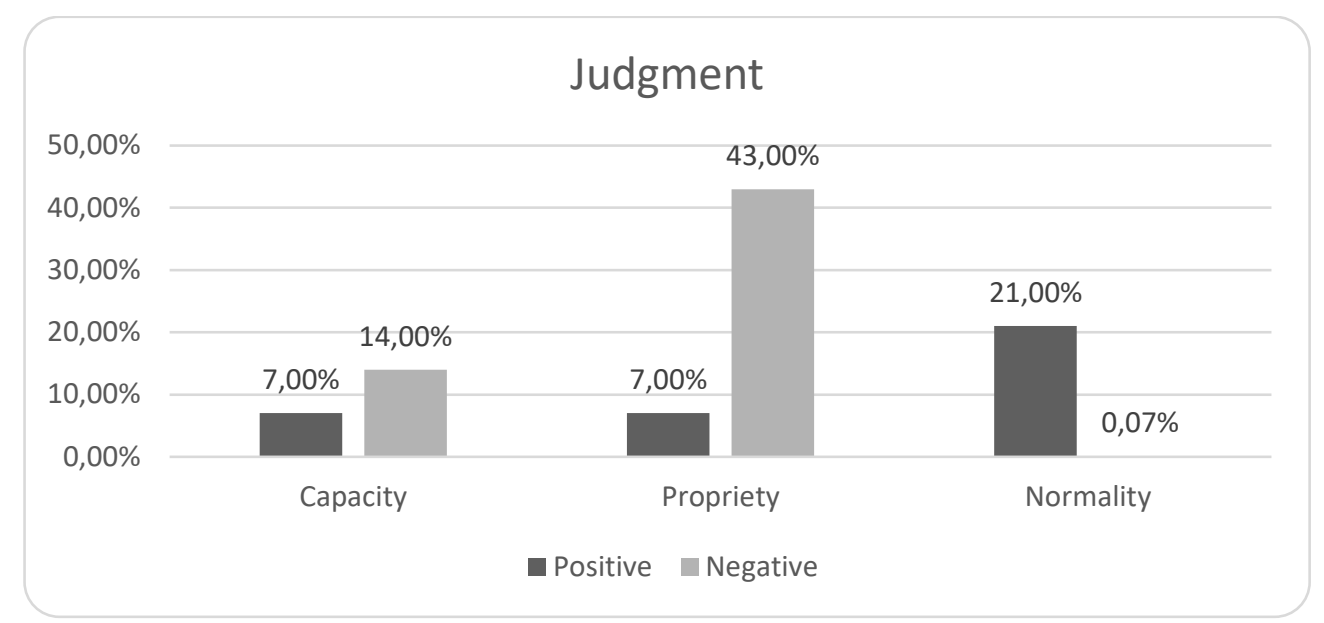

Figure 2. The Diagram of Judgment Findings

From the diagram, we can conclude that the writer stated $43 \%$ negative propriety or 6 times in 14 appraisal items. It shows that he has negative judgment towards the government by showing that their policies are beyond reproach, in negative ways.

\section{Appreciation (As a component of Attitude Analysis)}

It is analyzed related to the way things are valued or not in a given field by evaluating them in terms of semiotic and natural phenomena.

Negative reaction of impact in number (3) shows that the steps taken by the government does not please the writer or in other words, he is not happy with what has been done by the government.

Stating that the government and the public have similar responsibility (4) shows positive composition of balance showing that both parts can hang together.

The word abrupt (5) is a negative reaction of impact showing that the writer, again, is not pleased with the announcement given.

The positive reaction of quality is also shown with welcome (6) stating that the steps of extending the furlough scheme really pleases the writer.

But the negative reaction of quality is shown with tardy though this one is in the same sentence as welcome. So, besides showing that he is pleased with the extension, he also shows that he is displeased.

The positive reaction of quality is also shown in (9) where writer uses good to show that he is happy with the decisions taken by the government.

Negative reaction of quality in (10) describes that the condition happens nowadays grab writer's attention.

The complexity in composition of (11) describes that the writer assesses the condition or steps taken by the government are hard to follow. 
Negative reaction of impact which means that the phenomenon grabs writer's attention is stated in unfair, ill-advised referring to the rules from the government. The same appreciation is also given in (14) by giving negative evaluation to the policies and messages.

Negative valuation is given in (16) to answer the question "is it worthwhile?" and it seems that the phenomenon is not.

The clear explanation from Sir Simon seems grabbing the writer so he gives positive reaction of impact towards it.

But the negative word in (21) shows that the writer gives negative reaction of impact evaluation to the effects happen to individual.

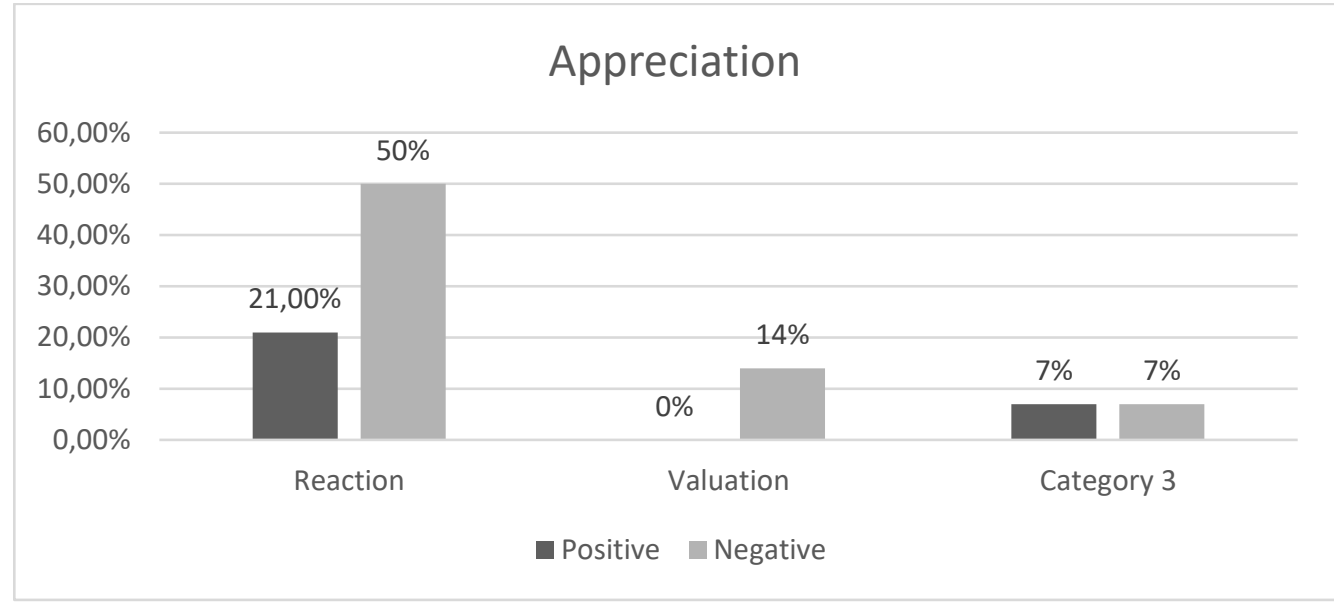

Figure 2. The Diagram of Appreciation Findings

This diagram shows the mostly shown in the editorial is negative reaction with 50\% occurrence. Or, in other words it occurs 7 times in 14 appraisal items.

\section{DISCUSSION}

Editorial section is considered as important part of a newspaper since it explicitly states the ideological stance of the news agency which is not stated in other part of the news (Lihua, 2009). In this study, editorial section was chosen to assess the political stance of The Guardian as one of the mass media in London reflected in their opinions related to how the government controls the pandemic in London. The editorial section may contain controversial opinions but it is assessed as the purest content indicating the stance taken by the media through persuasive and argumentative language.

From this editorial, it is found that there are 12 negative Affects. It means that the writer gives negative emotions towards what is happening in his environment nowadays especially to the policies issued by the government. Most of the negative Affect are related to unhappiness, especially, misery. The writer does not seem happy with the confusion or 
surprising steps taken by the government to handle the pandemic in his country.

The majority of judgment in the editorial is the negative condemn. It shows that the writer gives negative responses to any issues or messages delivered by the government. Very little positive judgment is found in the editorial showing that the writer does not see the policies in a good way.

Negative appreciation is delivered in the editorial by giving negative reaction showing that he evaluates the phenomena in negative ways.

Overall, the writer does not support the government agenda in handling the pandemic. However, the writer also gives some advice to the government in his editorial.

In this study, it is implied from the editorial that The Guardian is more likely does not stand on the same side as the government.

Editorial as a part of newspaper is expected to be able to give insight to students related to how to express their thoughts in form of writing. This supports the previous study of Amelia \& Muth'im (2021) stating that newspaper is helpful in improving students' ability in writing skill since they can learn the awareness in writing and some intrinsic factors from newspapers.

Understanding the attitude reflected in a text is considered important so students can get involved more in a discourse and think critically so later they can use the language started from the small unit, like word, appropriately.

The analysis of words choice in this study is considered different from the research done by Nasution \& Ayuningtias (2020) which analyzed the language use based on the sociolinguistic factors. This study analyzes the choice of words to determine the stance or like and dislikes towards things. This study is somewhat similar with a research by Prasetyanti (2011) involving President Soekarno speech which is analyzed based on attitude; affect, judgment and appreciations, there were 216 attitudes consisting of 107 affects, 61 judgment, and 48 appreciation. All the compound-complex sentences involve the use of attitude in it. The use of influence dominates the percentage of attitude. It is based on the reason that the speech was aimed to provoke and persuade people to stance a war against colonialism. But, Soekarno, as the orator used negative affect in higher percentage than the negative judgment. This can also be seen in other attitudes.

The results from this research can also be used as a model in terms of writing good text or speech by manipulating various lexico-grammatical for more detailed explanation. This thing, in the end, will improve the students' ability to write by choosing the proper vocabulary (diction) as the realization of interpersonal meaning. Second, the students will find that learning language does not mean they have to be able to be aware of the language use 
only but they are expected to be able to analyze their own text while delivering speech or doing public speaking as an orator. Language knowledge is prominent for the students to be able to produce good text.

Teaching students from the smallest unit like phoneme or words is considered helpful especially for EFL students. Involving scaffolding technique means lecturers need to guide the process of producing discourse. Instead of asking students to produce a text directly, it is better for them to get explanation about what the goal of producing the text, how the text should be delivered, what aspects need to be involved or included in the text and who will be involved in the text (Syarifah \& Gunawan, 2015). The similar scaffolding technique in introducing and teaching SFL was also proposed by Schulze (2015) stating that it accelerates students' literacy development.

\section{CONCLUSION AND SUGGESTION}

From this editorial, we can conclude that delivering displeasure or dissatisfaction can be done by using various words. It is necessary to choose our words carefully since it can be used by readers or speakers to assess our stance or affect towards something, to see how we judge and how we evaluate.

Teaching this knowledge with accurate and proper techniques, such as scaffolding instructions, will help students create better both spoken and written texts. For further researches, the implication of teaching this appraisal system to support the English Language Teaching is considered needed to be observed.

\section{REFERENCES}

Amelia, R., \& Muth'im, A. (2021). NEWSPAPERS EFFECT ON STUDENTS ' WRITING ACHIEVEMENT ACROSS ENGLISH. Journal of Applied Linguistics and Literature, 6(1), 97-108.

Awan, N. A., \& Harun, M. (2015). A Critical Analysis of Newspaper Editorial Discourse on the Portrayal of A Critical Analysis of Newspaper Editorial Discourse on the Portrayal of Uprising in Libya and Syria. June 2016.

Dong, T., \& Lin, X. (2018). Attitude in Appraisal Theory: A Comparative Analysis of English Versions of Changgan Xing.c.

Firmstone, J. (2015). Journalism Practice THE EDITORIAL PRODUCTION PROCESS AND EDITORIAL VALUES AS INFLUENCES ON THE OPINIONS OF THE BRITISH. June 2008. https:/ / doi.org/10.1080/17512780801999378

Firmstone, J. (2020). Editorial journalism and newspapers' editorial opinions Editorial Journalism and Newspapers' Editorial Opin - ions. June. https:/ / doi.org/10.1093/acrefore/9780190228613.013.803

Haristyanti, I. (2015). Appraisal in the 2013 inaugural address of president 
Barack Obama. Jurnal Ilmiah Mahasiswa FIB, 1(8).

Li, X. (2016). An Attitudinal Analysis of English Song Discourse from the Perspective of Appraisal Theory. 7(3), 559-565.

Martin, J. R., \& White, P. R. R. (2005). The Language of Evaluation.

Nasution, V. A., \& Ayuningtias, N. (2020). THE LANGUAGE CHOICE OF CHINESE COMMUNITY IN MEDAN : A SOCIOLINGUISTICS STUDY. Journal of Applied Linguistics and Literature, 5(1), 11-25.

Perales-escudero, M. D., Roo, U. D. Q., \& Roo, Q. (2018). Systemic-Functional Linguistics ( SFL ) and its applications. 42(2), 1-2. https:/ / doi.org/10.1177/003368820303400302

Perloff, R. M. (2003). The Dynamics of Persuasion.

Prasetyanti, D. C. (2011). APPRAISAL DEVICES USED TO REALIZE ATTITUDE IN SOEKARNO ' S SPEECH " LET A NEW ASIA AN AFRICA BE BORN" AT THE ASIAN-AFRICAN CONFERENCE IN BANDUNG ON APRIL 18 th, 1955.

Schulze, J. (2015). Academic Language, English Language Learners, and Systemic Functional Linguistics: Connecting Theory and Practice in Teacher Education. 109-130.

Syarifah, E. F., \& Gunawan, W. (2015). SCAFFOLDING IN THE TEACHING OF WRITING DISCUSSION TEXTS BASED ON SFL-GENRE BASED APPROACH. 4(1), 39-53.

Ugondo, P. I. (2018). INFLUENCE OF NEWSPAPER EDITORIALS ON VOTER ATTITUDE TOWARDS THE 2015 GENERAL ELECTIONS IN NIGERIA.

Wei, Y., Wherrity, M., \& Zhang, Y. (2015). An Analysis of Current Research on the Appraisal Theory i. 3(5), 235-239. https:/ / doi.org/10.13189/1ls.2015.030506 